This item was submitted to Loughborough's Research Repository by the author.

Items in Figshare are protected by copyright, with all rights reserved, unless otherwise indicated.

\title{
The situation of the 'Lords Room': a revaluation
}

PLEASE CITE THE PUBLISHED VERSION

PUBLISHER

C) Oxford University Press

LICENCE

CC BY-NC-ND 4.0

REPOSITORY RECORD

Egan, Gabriel. 2019. “The Situation of the 'lords Room': A Revaluation”. figshare. https://hdl.handle.net/2134/3754. 
This item was submitted to Loughborough's Institutional Repository (https://dspace.lboro.ac.uk/) by the author and is made available under the following Creative Commons Licence conditions.

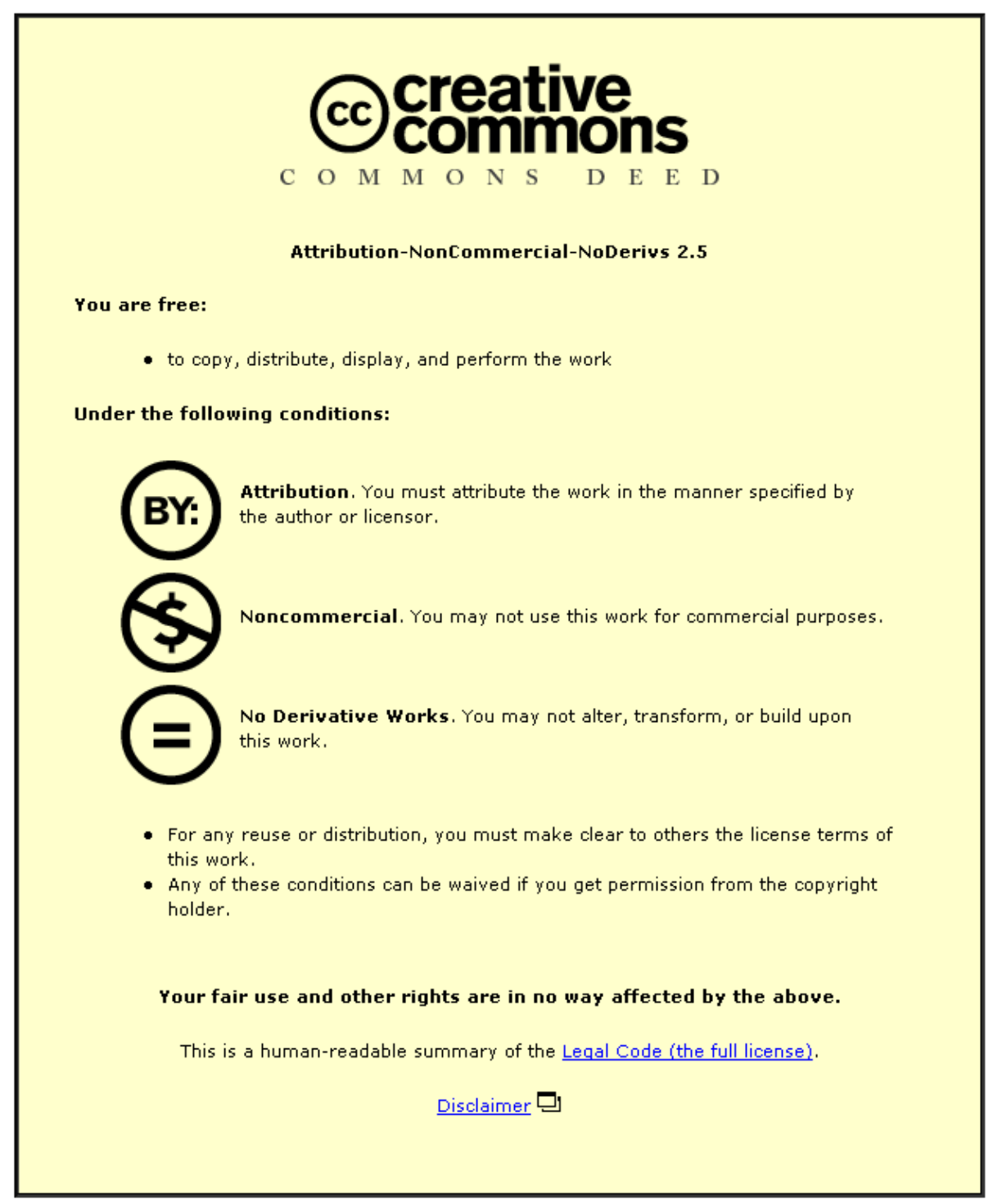

For the full text of this licence, please go to: http://creativecommons.org/licenses/by-nc-nd/2.5/ 


\author{
Gabriel Egan \\ Shakespeare Institute \\ Church Street \\ Stratford-on-Avon \\ CV37 6HP
}

\title{
29 March 1996
}

The Situation of the "Lords Room": A Revaluation

In his The Elizabethan Playhouse and Other Studies (1912) W. J. Lawrence argued that the term "Lords Room" found in contemporary documents referred to a spectating position in the stage balcony available to the most socially elevated members of the audience $^{1}$. It is not clear whether there was more than one such room, or how many lords it may have held, and I will retain the uncertainty by using the terms "Lords Room" and "Lords Rooms" without an apostrophe. Lawrence's conclusion that the Lords Room was in the stage balcony has been largely accepted and repeated with little revaluation of the evidence upon which it was based. The evidence for the use of the stage balcony as a spectating position is overwhelming, and has been cogently organized by Richard Hosley ${ }^{2}$. That this position was known as the Lords Room has not, however, been adequately shown, and there are good reasons to suspect that this term actually referred to some other spectating position.

The evidence consists primarily of allusions in early printed texts, dramatic and nondramatic, plus three pictures: De Witt's sketch of the Swan (1596), the vignette on the title-page of William Alabaster's Roxana (1632), and the frontispiece from Henry Marsh's The Wits (1662) ${ }^{3}$. These pictures show persons, probably spectators, in the stage balcony. Although I will refer in passing to the De Witt drawing, none of these illustrations can directly help us determine the location of Lords Room because no such label appears in them. In this paper the textual evidence will be organized into two categories: that which explicitly uses the term 'Lords Room', and that which refers to a position 'over the stage'. To avoid confusion the term 'gallery' will be used to denote only the auditorium scaffold encircling the stage and the yard (at the public amphitheatres), or the stage and the pit (at the private playhouses). The wide aperture half way up the frons scenae will be referred to as the 'stage balcony'.

The single most important piece of evidence, which refers to the Lords Room explicitly and in detail, is Thomas Dekker's The Guls Horne-booke (1609). Examination of the relevant passage will indicate that there is a problem with locating the Lords Room in the stage balcony:

Whether therefore the gatherers of the publique or priuate Play-house stand to receiue the afternoones rent, let our Gallant (hauing paid it) presently aduance himselfe vp to the Throne of the Stage. I meane not into the Lords roome, (which is now but the Stages Suburbs) No, those boxes by the iniquity of custome, conspiracy of waitingwomen and Gentlemen-Ushers, that there sweat together, and the couetousness of Sharers, are contemptibly thrust into the reare, and much new Satten is there dambd by being smothred to death in darknesse. ${ }^{4}$ 
Dekker's shift from a singular 'Lords roome' to a plurality of 'boxes' suggests that 'room' is being used not in the sense of 'An interior portion of a building divided off by walls or partitions' (OED sb. 8a) but rather of 'A place in which one is stationed or seated; a particular place assigned or appropriated to a person or thing' (OED sb. 11a). Both meanings were available to Dekker, but the alternative term 'chamber' was more commonly used when the former sense was required by writers of the period. This potential ambiguity must be borne in mind when considering any evidence which refers to a 'room' or 'rooms'. Dekker's Gallant of 1609 could sit either in the Lords Room or on the stage. The disadvantage of the former is that it has been 'contemptibly thrust into the reare' and made dark. This can be explained in several different ways. It may be that playhouse design has changed and the Lords Room has been moved. It could be that the terminology itself has altered and now refers to a less favourable position in the playhouse. It is possible that Dekker is using 'thrust into the reare' metaphorically (as he certainly is using 'suburbs') and that we need look no further than Lawrence's explanation that the Lords Room is simply not attracting the quality that it used to ${ }^{5}$. The simplest explanation, however, and the one that does most justice to Dekker's satirical purpose in this work, is that the very practice of sitting on the stage has effectively relegated the Lords Room to an inferior position by obscuring it. The gallant should sit on the stage because, if he were to sit in the Lords Room, he would be obscured by others sitting on the stage. Presumably the 'couetousness of Sharers' refers to the management's toleration of the practice because of the extra revenue generated. Certainly the Lords Room is represented as having declined in social status as a consequence of the increasing popularity of sitting on the stage. The ironic force of the passage, however, is in the rapidity with which onstage sitting becomes essential for the gallants because they cannot bear to be eclipsed: as soon as a few sit there they all must sit there.

Taken literally, Dekker's description of the change in aspect of the Lords Room at both the public and private playhouses raises an immediate problem. If the Lords Room is located in the stage balcony, an elevated position, no amount of crowding of the stage by sitters will obscure it. One way around this problem is to argue, as Herbert Berry has done, that the Lords Room was in the stage balcony at the public playhouses only, and that at the private playhouses the term refers to boxes at the side and the back of the stage which were insufficiently elevated to clear the heads of onstage sitters ${ }^{6}$. This argument requires that Dekker is referring primarily to the private playhouses when he talks of the darkening of the Lords Room, and that the only reason he says 'the publique or priuate Play-house' is that the practice of onstage sitting was, by 1609 , common to both. Indeed Berry thinks that Dekker refers to 'gulls moving onto the stage from "boxes" vaguely in the "reare"' and hence this can apply to 'Shakespearean playhouses generally" ${ }^{\prime 7}$ Berry must characterize Dekker as vague because he believes that at the public playhouses the Lords Room was in the stage balcony, which is much more above than it is behind the gallants on the stage, and he ignores the problem of those on the stage darkening the Lords Room. I hope to show that such reasoning is disconsonant both with the passage in question and with the rest of the evidence concerning playhouses in The Guls Horne-booke. It is also unnecessary since a more reasonable solution is available. Before considering the two main categories of evidence, it is worth considering the origins of the practice of sitting on the stage.

\section{The Origins of Sitting on the Stage}


E. K. Chambers believed that sitting on the stage first began before 1596, on the evidence of two epigrams by Sir John Davies ${ }^{8}$. In one of these, 'In Sillam', Davies mentions 'He that dares take Tabaco on the stage' and in another, 'In Rufum', he describes the actions of a gallant:

Rvfus the Courtier at the theatre, Leauing the best and most conspicuous place, Doth either to the stage himself transfer, Or through a grate doth shew his doubtfull face. ${ }^{9}$

Chambers, following C. R. Baskervill, believed these epigrams to have been written no later than $1596^{10}$. The subsequent discovery of a manuscript belonging to Davies's acquaintance Leweston Fitzjames has now fixed the date of composition firmly within 1595- ${ }^{11}$. No private theatres were open at this time, Paul's having closed in 1590 or $1591^{12}$, so Davies must be referring to public playhouse practice. John Orrell suggests that the provision of a stage cover encouraged well-dressed spectators to begin sitting on the stage ${ }^{13}$. Davies's 'In Rufum' is of further interest because the 'grate' through which Rufus 'doth shew his doubtfull face' is presumably the stage balcony with its vertical divisions separating the rooms. Since Rufus may move either onto the stage or into the stage balcony, his original location (the 'best and most conspicuous place') must have been neither of these. If the Lords Room was in the stage balcony there must have been an even better and more conspicuous place to sit. Or if the Lords Room was the best and most conspicuous place in the theatre, it was not in the stage balcony.

\section{'Over the Stage'}

There are three references to a spectating position described as 'over the stage' which are usually taken to indicate the Lords Room. The earliest is in Edward Guilpin's Skialetheia, in an epigram called 'Of Cornelius':

See you him yonder, who sits o're the stage, With the Tobacco-pipe now at his mouth? It is Cornelius the braue gallant youth, Who is new printed to this fangled age: ${ }^{14}$

Andrew Gurr cites this as evidence of the location of the Lords Room, but nothing in the epigram substantiates this claim ${ }^{15}$. That the stage balcony, if that is what 'over the stage' indicates, was a spectating position does not make it the Lords Room.

The two other references to 'over the stage' shed no light on the matter, yet both have been adduced to the argument that the Lords Room was in the stage balcony ${ }^{16}$. The first occurs in Dekker's and Wilkins's Jests to Make You Merie:

The 45. lest.

A wench hauing a good face, a good body, and good clothes on, but of bad conditions, sitting one day in the two-penny roome of a playhouse, \& a number of yong Gentlemen about her, against all whom she maintains talke. One that sat ouer the stage sayd to his friend: doe you not thinke that yonder flesh will stincke anon, hauing so many flyes 
blowing upon it. Oh (quoth his friend) I think it stinckes already, for I neuer saw so many crowes together, but there was some carion not far off. ${ }^{17}$

This indicates that wherever 'over the stage' was, it had a view of the two-penny room or rooms. The final example of this rubric is in The Dr. Farmer Chetham MS. Commonplace-Book, in 'A Description of Spongus the Gallant':

He playes at Primero over the stage, fighte for the wall, and keepes a lac'te Cloke page;

Ryde through the streetes in glisteringe braverie and swallowes not the least indignitie. ${ }^{18}$

The date of this epigram is uncertain, but Grosart believed that the entire manuscript was completed before 1625. It too tells us nothing other than that spectators could sit somewhere 'over the stage'. The De Witt drawing of the Swan in 1596 lends support to the idea that spectators sat in the stage balcony, although why the rest of the auditorium is depicted as empty is not clear. Similarly those in the stage balcony in the Roxana and The Wits pictures are probably spectators.

\section{Evidence for the Location of the Lords Room}

The earliest mention of the Lords Room is in an entry in Henslowe's account book recording payment for work done at the Rose in 1592:

pd for sellynge the Rome ouer the tyerhowsse... x s

pd for wages to the plasterer. ........ iiij s

pd for sellinges my lords Rome. ....... xiiij s

pd for makenge the penthowsse shed at the tyeringe

howsse doore as foloweth pd for owld tymber. . . . $\times \mathrm{s}^{19}$

Chambers suggested that Henslowe's phrase 'my lords Rome' may be in the genitive singular case, indicating 'not so much a room for "lords", as a room primarily reserved for the particular "lord", under whose patronage the actors played ${ }^{\prime 20}$. Hosley defended the usual interpretation of the phrase as being in the genitive plural case by pointing out that 'Henslowe is equally possessive about the Rose itself, which he more once refers to as "my playhowsse"'21. Chambers's comment might possibly indicate the origin of the term 'Lords Room', but it is clear that the place denoted became available for others to occupy. It is not clear exactly what is meant by 'the Rome ouer the tyerhowsse', but it cannot be the Lords Room whose ceilings are separately itemized as a greater expense. Lawrence suggested that it was the heavens hut, and Hosley agreed ${ }^{22}$. By "heavens hut" Lawrence meant 'the garret in the Swan sketch out of which the trumpeter is emerging' which he considered to be directly above the tiring house. Hosley has since argued that the De Witt drawing wrongly gives the impression that the hut is directly over the tiring house, which would be a highly impractical configuration, and that the back wall of the hut was actually in line with the frons and its front wall in line with the stage posts ${ }^{23}$. If indeed the Rose had such a heavens hut, and no matter where it was situated, the greatest difficulty in identifying it with Henslowe's 'Rome ouer the tyerhowsse' is that it would be absurd to provide such a room with a ceiling. We cannot be sure whether Henslowe here used the word 'ceil' (which could be spelt in a variety of ways) to mean 'To line the roof of, provide or construct an inner roof' (OED $\underline{v}$. 
3) or the less specific 'To cover with a lining of woodwork, sometimes of plaster, etc. (the interior roof or walls of a house or apartment)' (OED $\underline{\mathrm{v}} .2 \mathrm{a}$ ), both of which meanings were available at the time. We can, however, be sure what Henslowe meant by the word when used in the Fortune contract:

the said Peeter Street shall not be chardged $w^{\text {th }}$ anie manner of pay<ntin $>$ ge in or aboute the saide fframe howse or Stadge or anie pte thereof nor Rendringe the walls $\mathrm{w}^{\text {th }}$ in Nor seelinge anie more or other roomes then the gentlemens roomes Twoe pennie roomes and Stadge before remembred ${ }^{24}$

Since the contract distinguishes between the verbs 'render' and 'ceil', Henslowe must be using 'ceil' not in the general sense applicable to walls or ceilings but in the specific sense applicable only to ceilings. It is reasonable to suppose that Henslowe made the same distinction eight years earlier, and hence that he paid to have a ceiling installed in 'the Rome ouer the tyerhowsse' at the Rose. Since a heavens hut needs no ceiling (indeed it would be made less useful by the loss of headroom), we must look elsewhere. The most likely place to be the room over the tiring house is the spectating space in the stage balcony, and since the fitting of ceilings to the Lords Room is entered as a separate item of expense, the Lords Room cannot be in the stage balcony.

The next explicit reference to the Lords Room occurs in Jonson's Every Man Out of His Humour:

Carl[o] There's ne're a one of these but might lie a weeke on the racke, ere they could bring foorth his name; and yet hee powres them out as familiarly as if hee had seene 'hem stand by the fire $i$ ' the Presence, or ta'ne Tabacco with them ouer the stage $i$ ' the Lords roome. ${ }^{25}$

This is the only piece of evidence which links the expression 'over the stage' with the Lords Room. Evidence drawn from the dialogue of plays is not the same as evidence from building contracts or account books, and must be considered within its dramatic context. The play is full of metatheatrical dialogue in which the worlds of the play and of the playhouse are conflated. Possibly the actor playing Carlo gestures to the Lords Room as he speaks the line, to create yet another artifice-collapsing effect. If Carlo is merely referring to an abstract playhouse in the world of the play, the clause 'ouer the stage i' the Lords roome' is oddly pleonastic, since the audience may be expected to know the layout of a playhouse. But if he is making a gesture it is possible that 'ouer the stage' means "across the stage", in other words "over there" 26.

There is one more direct reference to the Lords Room to consider. In Dekker's Satiromastix Horace, representing Jonson, is forced to accept modifications to his habitual behaviour at playhouses:

Sir Va[ughan] Moreouer, you shall not sit in a Gallery, when your Comedies and Enterludes haue entred their Actions, and there make vile and bad faces at euerie lyne, to make Sentlemen haue an eye to you, and to make Players afraide to take your part.

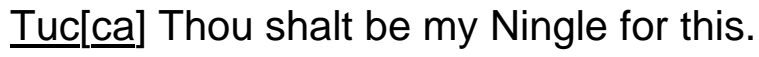


Sir Vau[ghan] Besides, you must forswear to venter on the stage, when your Play is ended, and to exchange curtezies, and complements with Gallants in the Lordes roomes, to make all the house rise vp in Armes, and to cry that's Horace, that's he, that's he, that's he, that pennes and purges Humours and diseases. ${ }^{27}$

It has been argued that the Blackfriars theatre only is being referred to here, because Jonson was its resident dramatist in $1602^{28}$. However, Horace is being made to swear not to do the things he habitually does and this diminishes the sense of a specific place being referred to; it is Jonson's general way of behaving that is being censured. If the intention is to mock habits that Jonson has displayed only at the Blackfriars then the allusion is to recent behaviour (since the last quarter of 1600), and the force of the attack is diminished by this specificity ${ }^{29}$. It might be argued that the two injunctions (not to distract the players and audience, and not to venture onto the stage) refer to two occasions at two different playhouses, but since the first prescribes what Horace may do during, and the second after, a performance, it seems that a single occasion is intended.

Wheresoever Horace has been displaying this behaviour, the Lords Room and the stage are sufficiently close to one another for Horace to stand on the latter and 'exchange curtezies, and complements with Gallants' in the former. Let us assume first that Horace's behaviour at the public playhouses is being mocked. His seat during the performance cannot be in the same place as the Lords Rooms since it is absurd to forbid him to leave his seat in order to address those in the place he has just left. Horace's spectating position must be somewhere other than the Lords Room, from where he could pull faces to distract the players and the gentlemen, and afterwards 'venture on the stage'. There are only two possibilities: Horace sits in a gallery near the stage and the Lords Room is in the stage balcony, or Horace sits in the stage balcony and the Lords Room is in a gallery near the stage. In the first hypothesis Horace is not well placed to distract anyone by pulling faces, and unless there is direct access between the tiring house and the ends of the galleries closest to the stage, it would be extremely difficult for him to get onto the stage after the play ${ }^{30}$. He would have to scramble past many other spectators, emerging either in the yard or outside the playhouse (depending on how access to the galleries is controlled) and then make his way onto the stage. But in the second hypothesis, if Horace sits in the stage balcony he is well placed to distract the players and the general eye, and also to venture directly onto the stage via the tiring house. If Satiromastix informs us of the Lords Rooms at the public playhouses, they are probably not in the stage balcony.

Now let us suppose Berry is right in thinking that Jonson's behaviour at Blackfriars alone is being mocked. The same arguments apply with equal force: Horace's seat and the Lords Room must be different places and the former must be a 'gallery' and have ready access to the stage. If Horace is at the side of the stage--which might still be 'in a gallery' if the galleries continued over the stage--then certainly at Blackfriars it is easy for him to venture onto the stage from there, but that still leaves us looking for somewhere else to call the Lords Room. Berry posits boxes in the wall behind, and on the same level as, the stage and argues that these are the Lords Rooms ${ }^{31}$. The stage balcony is not a suitable location because of the restricted height of the room itself and, more importantly, because 'the difficult angle of vision created by the height and the proximity of the seats to the stage' would limit the number of box seats with a good view $^{32}$. Burbage's solution, argues Berry, was to move the Lords Room down the back 
wall: from an elevated position in the stage balcony at the public playhouses to a stagelevel position at the Blackfriars. This configuration is not implausible, but it is clear that the evidence of Satiromastix cannot be used to argue that the Lords Room was in the stage balcony, no matter which theatre or theatres we think Dekker is indicating.

\section{The Guls Horne-booke}

The date of printing, 1609, makes the evidence of The Guls Horne-booke potentially relevant to either the public or the private playhouses or both. In the proemium, Dekker refers to 'the twelue penny roome next the stage' and Berry thinks it is 'better than a fair guess' that this refers to the Blackfriars ${ }^{33}$. In fact the passage that Berry cites contains certain proof that, for this passage at least, Dekker is thinking of the public playhouses:

I coniure you (as you come of the right Goose-caps) staine not your house; but when at a new play you take up the twelue-penny roome next the stage, (because the Lords \& you may seeme to be haile fellow wel met) there draw forth this booke, read alowd, laugh alowd, and play the Antickes, that all the garlike mouthd stinkards may cry out, Away with the foole ${ }^{34}$

The use of the expression 'garlike mouthd stinkards' makes it clear that Dekker is referring to the public playhouses. In The Ravens Almanacke of the same year Dekker refers to the actor 'glad to play three houres for two pence to the basest stinkard in London, whose breath is stronger then Garlicke, and able to poyson all the 12. penny roomes $^{\prime 35}$. This is a formulaic attack on the dirty and smelly groundlings, and cannot possibly suggest the private playhouses. In the passage from the proemium of The Guls Horne-booke quoted above, the point of taking the twelve-penny room is to attract the attention of the Lords and give the appearance of exchanging acknowledgements with them. If the lords are in a Lords Room in the stage balcony, the twelve-penny rooms at the side of the stage are not well placed to attract their attention. But if the Lords are also in a gallery at the side of the stage, either on the same side or perhaps more plausibly on the opposite side of the stage, then the gallant is very well placed to exchange acknowledgements with them.

Andrew Gurr, citing the sixth chapter ('How a Gallant should behave himself in a Playhouse') of The Guls Horne-booke, says that 'His remarks are meant to apply to any playhouse, but fit best at the leading hall playhouse ${ }^{36}$, that is, the Blackfriars. In fact there is clear evidence throughout the chapter that, although the private playhouse is mentioned, the public amphitheatres are uppermost in Dekker's mind:

Sithence then the place is so free in entertainement, allowing a stoole as well to the Farmers sonne as to your Templer: that your Stinkard has the selfe same libertie to be there in his Tobacco-Fumes, which your sweet Courtier hath: and that your Car-man and Tinker claime as strong a voice in their suffrage, and sit to giue iudgement on the plaies life and death, as well as the prowdest Momus among the tribe of Critick: It is fit $\mathrm{y}^{\mathrm{t}}$ hee, whom the most tailors bils do make roome for, when he comes should not be basely (like a vyoll) casd up in a corner. ${ }^{37}$

The reference to tinkers and stinkards shows that Dekker is thinking of the public amphitheatres here. The paragraph following this contains the advice to sit on the stage rather than in the Lords Room, and the idea is introduced in this paragraph by 
the expression 'casd up in a corner'. A Lords Room in the stage balcony could scarcely be said to be in a corner, but a box at the extreme end of a gallery, abutting the tiringhouse side and facing the stage at an oblique angle, certainly is.

Dekker's next paragraph begins with the famous remarks concerning the darkening of the Lords Room (quoted p. 3 above), and continues:

But on the very Rushes where the Commedy is to daunce, yea and vnder the State of Cambises himselfe must our fetherd Estridge, like a peece of Ordnance be planted valiantly (because impudently) beating downe the mewes \& hisses of the opposed rascality. ${ }^{38}$

As I have suggested, it is the practice of sitting on the stage that has darkened the Lords Room, and this indicates that the Lords Room is not in the stage balcony because such a position could not be obscured. Presumably the mews and hisses come from those waiting-women and gentlemen-ushers whom the gallant obscures, that is, from the 'opposed rascality'. That they are 'opposed' indicates more than their objection: it shows that they are on approximately the same level as the stage. Those in the yard are not 'opposed' but underneath. The Lords Room is clearly in the lowest gallery.

The gentlemen-ushers and waiting-women are not lords and yet Dekker uses the term Lords Room. This suggests a stability of terminology unaffected by the social status of the occupants of this position. If the Lords Room was the name given to wherever the nobility were currently finding it desirable to sit, Dekker's witticisms would not be intelligible to his readers. In the absence of any evidence for a change in the place denoted by the term Lords Room, I propose a continuity throughout the period from the first public amphitheatre to the closing of the theatres in 1642.

In the next few paragraphs of The Guls Horne-booke Dekker lists the advantages to be gained by sitting on the stage, which are so great that

neither are you to be hunted from thence though the Scar-Crowes in the yard, hoot at you, hisse at you, spit at you, yea throw durt euen in your teeth: tis most Gentleman like patience to endure all this, and to laugh at the silly Animals, but if the Rabble with a full throat, crie away with the foole, you were worse then a mad-man to tarry by it: for the Gentleman and the foole should neuer sit on the Stage together. ${ }^{39}$

The reference to the yard shows that Dekker is thinking of the public playhouses. That he deals here with the yardlings' reaction to the onstage sitters makes it likely that the earlier reference to hissing and mewing was concerned with the objectors in the Lords Room and not those in the yard. At the end of the chapter the problem of getting home across the Thames is discussed, and this too indicates that the public amphitheatres of Southwark are Dekker's primary subject. If we recognise that Dekker is not referring primarily to the Blackfriars theatre, we are left with further evidence that at the public playhouses the Lords Room was in the lowest auditorium gallery close to the stage. Of the private playhouses we know only that Dekker chose to make the same remarks applicable to either 'the publique or priuate Play-house'. The evidence of The Guls Horne-booke does not indicate that the Blackfriars deviated from the public theatre configuration, rather that its Lords Room was in approximately the same place. 


\section{Conclusion}

In his work on the location of the Lords Room W. J. Lawrence was concerned to dismiss the 'alternation theory' of Cecil Brodmeier which rested in part upon the existence of a large upper stage upon which scenes could be played while the closedoff alcove below was made ready for a subsequent scene. In making the case for spectators sitting in the stage balcony the followers of Lawrence have adduced all the available evidence to this end, and so produced the equation of stage balcony with Lords Room that still persists. Even as late as 1987 Herbert Berry, in a revised version of an article first published in 1966, considered it worth commenting that his work on the boxes at Blackfriars could 'lend a little force to th[e] attack' on the myth of an alcove and an upper-stage ${ }^{40}$.

In the third edition of The Shakespearean Stage 1574 - 1642 Andrew Gurr implicitly rejects the custom of sitting on the stage in the public playhouses of the $1590 \mathrm{~s}^{41}$. Concerning the earliest theatres, including the Red Lion in Stepney, Gurr writes that patrons of highest social status 'sat in a special section of the galleries closest to the stage called the "lords" rooms' ${ }^{42}$. At the Theatre, Rose and Globe there were 'lords' rooms costing $6 \underline{\mathrm{d}}$., partitioned off from the galleries closest to the stage ${ }^{\prime 43}$. This inclusion of the Globe amongst those with the same configuration as the Red Lion is a tacit statement of continuity of location of the Lords Room from 1567 to 1599 . Such continuity is necessary to my argument and is borne out by Dekker's description of the change of clientele (and hence continuity of location) of the Lords Room by 1609. Later Gurr writes of the first Globe that 'above the stage-level in the frons were the lords' rooms ${ }^{\prime 44}$, which contradicts his earlier statements unless he means to imply, without evidence, that the Lords Rooms were moved. Despite Dekker's use of the term Lords Room in The Guls Horne-booke, which he believes to be most applicable to the Blackfriars, Gurr avoids using the term in relation to the private theatres. He writes only that 'boxes flanking the stage' had a better view than 'the equivalent lords' rooms in the amphitheatres', and that Inigo Jones's design for a hall playhouse based on the Blackfriars had 'space for seating on the balcony where the lords' rooms were positioned at the Globe'45

To argue, as I have done, that the Lords Room was in the lowest gallery at the side of the stage is to risk conflating it with the 'gentlemen's rooms' which the contract for the building of the Fortune theatre suggests were there:

$\mathrm{w}^{\text {th }}$ ffower convenient divisions for gentlemens roomes and other sufficient and convenient divisions for Twoe pennie roomes $w^{\text {th }}$ necessarie Seates to be placed and sett Aswell in those roomes as throughoute all the rest of the galleries of the saide howse ${ }^{46}$

Hosley is typical of the scholarly consensus in arguing that the only logical location for such divided-off seating is at the far ends of the lowest gallery nearest the stage ${ }^{47}$. The vertical positioning at least is confirmed by the contract to build the Hope theatre, which says that Gilbert Katherens shall make 'Two Boxes in the lowermost storie fitt and decent for gentlemen to sitt in / And shall make the $p<$ ar>ticõns betwne the Rommes as they are at the saide Plaie house called the Swan' ${ }^{\prime 4}$. Perhaps the Lords Room might also be referred to as a "gentlemen's room", since a lord is certainly a gentlemen even though the reverse is not true. If the two terms referred to different places, it is possible 
that they formed matched pairs flanking the stage, one of each on each side, or even that the Lords Room occupied one side of the stage while the gentlemen's rooms occupied the other. The currently available evidence does not allow certainty on this matter. This is not to say, however, that the evidence requires us to use the terms interchangeably in the way that Gurr appears to when locating the Globe's Lords Rooms first at the side of the stage and then in the stage balcony, without discussing the relocation ${ }^{49}$.

If the Lords Room is taken to mean a spectating position at the side of the stage at both the public and the private playhouses throughout the period then many of the problems I have described disappear and we can make sense of Dekker using the same term in 1609 as Henslowe in 1592. Locating the Lords Room at the side of the stage also eliminates the awkward, but not decisive, problem that the lords cannot see discoveries if they are sitting in the stage balcony. The only evidence to the contrary, which raises the possibility that the Lords Room was in the stage balcony, is the phrase 'ouer the stage in the Lords roome' in Jonson's Every Man Out of His Humour. On its own, and subject to varied interpretations, this is insufficient to counteract the overwhelming evidence that the Lords Room could not have been in the stage balcony.

\section{Notes}

${ }^{1}$ W. J. Lawrence, The Elizabethan Playhouse and Other Studies (Stratford-upon-Avon, 1912).

${ }^{2}$ Richard Hosley, 'The Gallery over the Stage in the Public Playhouse of

Shakespeare's Time', Shakespeare Quarterly, 8 (1957), 15-31.

${ }^{3}$ All three are reproduced in R. A. Foakes, Illustrations of the English Stage 1580-1642 (London, 1985).

${ }^{4}$ Thomas Dekker, The Guls Horne-booke (London, 1609), sig. E2 .

${ }^{5}$ Lawrence, The Elizabethan Playhouse, p. 31.

${ }^{6}$ Herbert Berry, Shakespeare's Playhouses (New York, 1987), pp. 50-66.

${ }^{7}$ Berry, Shakespeare's Playhouses, p. 65.

${ }^{8}$ E. K. Chambers, The Elizabethan Stage, 4 vols. (Oxford: Clarendon Press, 1923), vol. 2, p. 535.

${ }^{9}$ Sir John Davies, and Christopher Marlowe, Epigrammes and Elegies (Middleborough, 1595-6), sig. A4. The line from 'In Sillam' appears on sig. C2.

${ }^{10}$ C. R. Baskervill, 'The Custom of Sitting on the Elizabethan Stage', Modern Philology, 8 (1911), 581-89; pp. 582-3.

${ }^{11}$ Robert Krueger, 'Sir John Davies: Orchestra Complete, Epigrams, Unpublished Poems', The Review of English Studies, ns, 13 (1962), 113-24. 
12 Reavley Gair, The Children of Paul's: The Story of a Theatre Company, 1553-1608 (Cambridge, 1982), p. 112.

13 John Orrell, The Human Stage: English Theatre Design, 1567-1640 (Cambridge, 1988), p. 90.

${ }^{14}$ Edward Guilpin, Skialetheia, or A Shadow of Truth in Certaine Epigrams and Satyres (London, 1598), sig. B1.

${ }^{15}$ Andrew Gurr, The Shakespearean Stage 1574 - 1642, 3rd edn (Cambridge, 1992), p. 147.

${ }^{16}$ By Richard Hosley in his 'The Gallery Over the Stage in the Public Playhouses of Shakespeare's Time', p. 24, and Andrew Gurr in Playgoing in Shakespeare's London (Cambridge, 1987), pp. 21, 221. Gurr does not discuss the connection between Dekker's Jest no. 45 and the Lords Room, but his index entry for 'Playhouses; lords' room' (p. 281) points the reader to his reproduction of it in Appendix 2 (p. 221).

17 Thomas Dekker, and George Wilkins, Jests to Make You Merie (London, 1607), sig. $\mathrm{C} 3{ }^{\mathrm{V}}-\mathrm{C} 4$.

${ }^{18}$ Rev. Alexander B. Grosart, ed., The Dr. Farmer Chetham MS. Commonplace-Book, 2 vols. (Manchester, 1873), vol. 1, p. 104. Grosart discusses the date of composition on p. iv.

${ }^{19}$ R. A. Foakes, and R. T. Rickert, eds, Henslowe's Diary, Edited With Supplementary Material, Introduction and Notes (Cambridge, 1961), p. 13.

${ }^{20}$ Chambers, The Elizabethan Stage, vol. 2, p. 535.

${ }^{21}$ Hosley, 'The Gallery Over the Stage in the Public Playhouses of Shakespeare's Time', p. 25n19.

${ }^{22}$ Lawrence, The Elizabethan Playhouse, pp. 33-34; Hosley, 'The Gallery over the Stage in the Public Playhouse of Shakespeare's Time' p. 25n19.

${ }^{23}$ Richard Hosley, 'The Stage Superstructures of the First Globe and the Swan', in 'The Shape of the Globe' and 'The Interior of the Globe': Reports on Seminars held on 29 March 1983 and 12 April 1986, ed. by Ronnie Mulryne and Margaret Shewring, The Renaissance Drama Newsletter Supplements, 8 (Coventry, 1987), pp. 42-78. See also John Orrell's detailed rebuttal of Hosley's argument, in the same volume pp. 103-7.

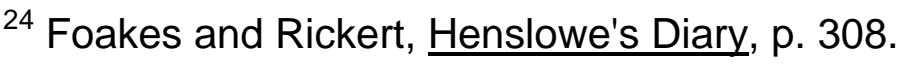

${ }^{25}$ Ben Jonson, Every Man Out of His Humour, Quarto 1 (London, 1600), sig. F3.

${ }^{26}$ OED 'over' prep. 15a. This sense was available at the time.

27 Thomas Dekker, Satiromastix, or The Untrussing of the Humorous Poet (London, 1602), sig. M1. 
${ }^{28}$ Herbert Berry, Shakespeare's Playhouses, p. 51.

${ }^{29}$ For the evidence that the Children of the Chapel did not begin using Blackfriars before the last quarter of 1600 , see Irwin Smith Shakespeare's Blackfriars Playhouse: Its History and Its Design (New York, 1964), pp. 177-8.

${ }^{30}$ Such access was suggested by Richard Southern in 'On Reconstructing a Practicable Elizabethan Public Playhouse', Shakespeare Survey 12 (1959), 22-34; p. 30 . This idea has not been taken up by subsequent reconstructors of playhouses.

${ }^{31}$ Berry, Shakespeare's Playhouses, pp. 54-5.

${ }^{32}$ Berry, Shakespeare's Playhouses, pp. 56-7.

${ }^{33}$ Berry, Shakespeare's Playhouses, pp. 51.

${ }^{34}$ Dekker, The Guls Horne-booke, sig. B1 ${ }^{v}$.

${ }^{35}$ Thomas Dekker, The Ravens Almanacke (London, 1609), sig. C1v.

${ }^{36}$ Gurr, The Shakespearean Stage, p. 227.

${ }^{37}$ Dekker, The Guls Horne-booke, sig. E2v .

${ }^{38}$ Dekker, The Guls Horne-booke, sig. E2 ${ }^{v}$.

${ }^{39}$ Dekker, The Guls Horne-booke, sig. E3.

${ }^{40}$ Berry, Shakespeare's Playhouses, p. 65.

${ }^{41}$ Gurr, The Shakespearean Stage, pp. 12, 164, $255 n 69$.

${ }^{42}$ Gurr, The Shakespearean Stage, p. 116.

${ }^{43}$ Gurr, The Shakespearean Stage, p. 122.

${ }^{44}$ Gurr, The Shakespearean Stage, p. 147.

${ }^{45}$ Gurr, The Shakespearean Stage, p. 159.

${ }^{46}$ Foakes and Rickert, Henslowe's Diary, p. 307.

${ }^{47}$ Richard Hosley, 'A Reconstruction of the Fortune Playhouse: Part 2', in The Elizabethan Theatre VII: Papers given at the Seventh International Conference on Elizabethan Theatre held at the University of Waterloo, Ontario, in July 1977, ed. by G. R. Hibbard (London, 1981), pp. 1-20; p. 6.

${ }^{48}$ Walter W. Greg, ed., Henslowe Papers: Being Documents Supplementary to Henslowe's Diary (London, 1907), p. 20. 
${ }^{49}$ More recently Gurr has written that 'The "lords' rooms" were evidently distinct from the "twopenny galleries" and even from the "gentlemen's rooms" noted in the Fortune and Hope contracts' in 'The Bare Island', Shakespeare Survey 47 (1994), 29-43; p. 38. 